DOI: https://doi.org/10.47405/aswj.v5i2.135

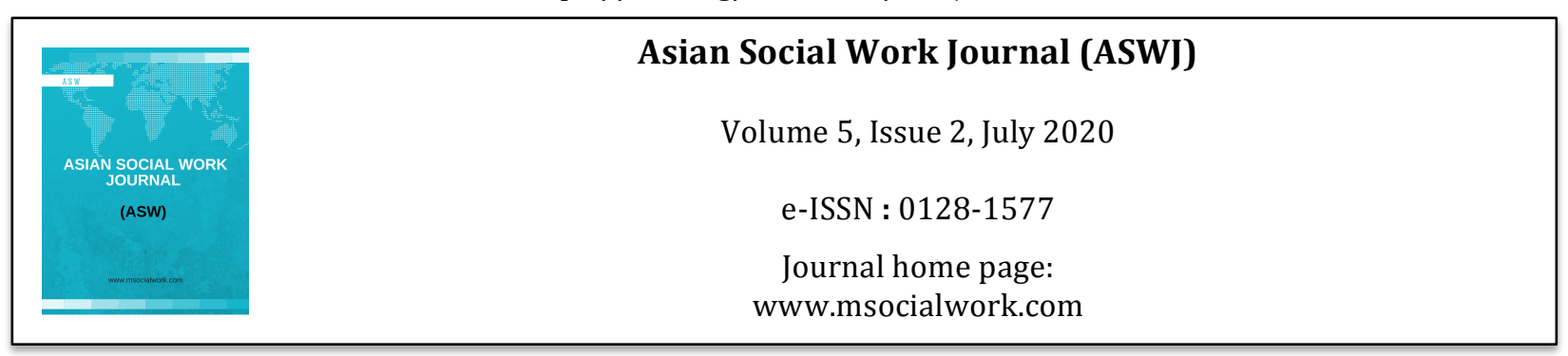

\title{
A Situation Analysis of Higher Secondary Tribal Residential Schools in Tiruvannamalai District, Tamil Nadu, India
}

\author{
Bala Krishnan. $\mathbf{S}^{1}, \mathbf{S}$. Sudharsan ${ }^{1}$ \\ ${ }^{1}$ Department of Social Work (Aided), Madras Christian College, Chennai, India \\ Correspondence: Bala Krishnan. S (balakrishnan.s108@gmail.com)
}

\begin{abstract}
Education for tribal communities has become one of the prime focuses which is taken into account as an integral a part of socio-economic development of Schedule Tribes in Asian country. Within the recent years, there has been some improvement in providing the education for the tribal communities. The implementation of Government Tribal Residential Schools has an important role to play in raising literacy rate. With regard to the literacy rate of the tribes in Tamil Nadu is 54.34 percent. As 83.08 per cent of the tribal survives in hilly/rural areas and 16.91 per cent of them live in urban (town) areas (2011 Census). The status of Education in Tamil Nadu for Scheduled Tribe is worser than other states of the country. Tamil Nadu is ranked third compared to all over literacy rate. In case of ST $(41.53 \%)$ still it is lower than the general sections $(73.57 \%)$ of the society. The socio-economic backwardness, lack of good education facility and asymmetrical structure of the society are the reasons for being lower caste of ST. The objective of the study is to understand the impact of the Tribal residential school, set up within the tribal area of Jawadhi a hilly area in the District Tiruvannamalai. And also, the challenges faced by the students in the school. Data was collected through Interview and observation. This study intends to evaluate the Tribal Residential School with the objective to find whether the design of programme is appropriate to meet the stated objectives, whether there is any impact in decreasing the dropout rates of STs. Moreover, it will also reveal about the efficacy with which the mechanism of education promotion is pending in the process of implementation and the need for the efficient mechanism to develop it for the empowerment of tribes. The main objective of residential schools for Scheduled Tribes (STs) students is to provide quality education to tribal students. The study suggests, to follow the guidelines that indicate the organizational structure, Manpower and Educational expertise for the Tribal welfare Department. All these tribal residential school should have separate budget plan for infrastructure, recurring, non-recurring expenditure every year and it should be included in the annual work plan \& budget.
\end{abstract}

Keywords: tribal studies, tribal education, residential schools, South India

\section{Introduction}

The economic, social, cultural progress of a nation is determined by the education development of its citizen. Scheduled Tribes are economically backward and historically lower as a specific group in the overall population of the country. Educational development is the most prominent tool for empowerment and has the capability to ascertain the marginalized people. Tamil Nadu is placed third in overall literacy rate, while in case of ST (41.53\%) it is still lower than the general sections $(73.45 \%)$ of the society. Education is the key functioning of the human development but when it comes to ST there is lack of education and the literary rate is low. The researcher is carrying out this study to find 
DOI: https://doi.org/10.47405/aswj.v5i2.135

out the effectiveness of tribal residential school's functioning and its purpose. Tiruvannamalai is the only District has three different categories of education institution (Tribal residential school) within the distance of $20 \mathrm{~km}$ radius, as these schools are running by different administration such as Government Tribal Residential school (GTR school), Eklavya Model Residential School (EMRS) and Tribal Higher Secondary School (THSS), Guniganthur, Society for Rural Development (SFRD), an NGO which has same curriculum but different facilities and teaching methodology has been practiced in the above schools under Tribal welfare department.

A situation analysis of Higher Secondary Tribal Residential Schools in Tiruvannamalai District, Tamil Nadu.

\section{Specific Objective}
i. To compare the availability of human and structural facilities of different schools.
ii. To understand the perception of different stakeholders on the educational service.
iii. To understand the socio-cultural milieus of each schools.

\section{Research Method}

The Research method followed in this study is "Descriptive Research". The researcher has chosen the mentioned research method based on the basic objective of the study was to examine the problem faced the students and teachers in the residential school managed by different systems.

\section{Field of Study}

The study were conducted on the following three schools as only these are the schools which has higher secondary level of education for the welfare of Tribal community such as Government Tribal Residential School (GTR School) Nimmiyampattu - a State Government School, Eklavya Model Residential School (EMRS) - a Model School of Central Government and State Government and Tribal Higher Secondary School (THSS), Guniganthur - an Society for Rural Development (SFRD) NonGovernmental Organization in Tiruvannamalai District. All these three schools are coming under the jurisdiction of the Department of Tribal Welfare, Government of India.

\section{Sampling Framework}

The study population for this research is students and teachers from class $9^{\text {th }}$ to $12^{\text {th }}$ std of the three schools Government Tribal Residential School (GTR School), Eklavya Model Residential School (EMRS), Tribal Higher Secondary School (THSS), Guniganthur situated at Nimmiyampattu, Kavalur, Guniganthur of Tiruvannamalai district.

The total size of the population for the study was 1100 students, 27 teachers including class teacher and Head master in three schools (by the school records from $9^{\text {th }}$ std to $12^{\text {th }}$ std). In which, the researcher took $10 \%$ of the respondents from total size as the representatives of the student's population and the whole population of the teachers. Total size for the study is 110 students and 27 teachers. (Refer Table 1 and Table 2).

Table 1: Distribution of sample size among Students

\begin{tabular}{ccccc}
\hline \multirow{2}{*}{ District } & Village & School & $\begin{array}{c}\text { Total Population of Sample size (10\% of the } \\
\text { population) }\end{array}$ \\
\hline \multirow{4}{*}{ Tiruvannamalai } & Nimmiyampattu & GTR & 192 & 19 \\
& Kavalur & EMRS & 122 & 12 \\
& Guniganthur & THSS & 786 & 79 \\
& Total & & $\mathbf{1 1 0 0}$ & $\mathbf{1 1 0}$ \\
\hline
\end{tabular}


DOI: https://doi.org/10.47405/aswj.v5i2.135

Table 2: Distribution of sample size among Teachers

\begin{tabular}{|c|c|c|c|}
\hline District & Village & School & Total Population of Teachers \\
\hline \multirow{4}{*}{ Tiruvannamalai } & Nimmiyampattu & GTR & 6 \\
\hline & Kavalur & EMRS & 6 \\
\hline & Guniganthur & THSS & 15 \\
\hline & \multicolumn{2}{|c|}{ Total } & 27 \\
\hline
\end{tabular}

\section{Sampling Procedure}

The researcher used proportionate random sampling for student population using lottery method. The researcher used Purposive sampling for teacher population.

\section{Tool for Data Collection}

The researcher used "Interview schedule" as a tool for data collection as the research was among the Tribe schools the researcher used an Interview schedule and translated copy of it. In this way the researcher was able to get accurate data from respondents.

An interview schedule is basically a list containing a set of structured questions that have been prepared, to serve as a guide for interviewers, researchers and investigators in collecting information or data about a specific topic or issue.

\section{Findings}

Majority of the respondent's belongs to rural village of Tiruvannamalai District and their family's monthly income is between Rs.5000 - Rs. 10000 and 30\% of the respondents and their family's primary occupation is Agriculture.

\section{Infrastructure Facilities}

Library is one of the most important place for a quality learning and teaching but it has not been given due importance by any school.

The facilities are not adequate and there is no proper maintenance. Accommodation are available only for staffs in THSS school, but additional space is required and (a) Toilets (b) Staff Quarters and dormitories for other schools are required and for (c) Laboratory also but expect THS school where it is available. Poor maintenance in all the school buildings, especially in kitchen, dormitories and toilets. Construction of Conference Hall, Recreation Hall/ Auditorium, Computer Lab, Store Room, Sports Room, Sick Room, Toilets for students is needed.

Lack of proper infrastructure, no proper sized class room, fan, air circulation, lighting, window, toilets for students are the main drawback of all the schools and lack of well-furnished science laboratory, computer labs are main drawbacks of both GTR and EMR schools.

\section{Boarding Facilities}

The quantity and quality of food is very important and especially for residential schools it is need to be ensured. The quality of food supplied to the students are very poor in quality as well as in quantity but expect in EMR school where the regular food schedule is also followed. 
DOI: https://doi.org/10.47405/aswj.v5i2.135

\section{Lodging Facility}

In all the three schools' rooms are not clean, bath-rooms and toilets are inadequate which cause students distress and there is no availability of bed with cot, more number of students is accommodated in one room.

\section{Kitchen and Dining Halls}

Dining halls are not furnished in other schools but expect EMR school. The students sit in the floor and ground around the kitchen.

\section{Outdoor Facilities:}

The GTR school has no open ground space and no compound wall where the safety of students is questionable.

\section{Games and Sports:}

Whereas open ground is available in EMRS and THHS for playing but sports material are not provided as they don't have a period of PT in their time table.

\section{Co-Curricular Activities:}

No extra co-curricular activities are allowed and engaged for students expect on school annual day function.

The study reveals that due to in sufficient availability of the teachers, the same teachers are handling one or two subjects for the students. The availability of regular health camps are regular for girls but not for boys. The GTR School has an irregularity of teacher to school because of the bus facility in the slopes. Majority of the respondents said that they are not satisfied with samacheer kalvi syllabus. Out of 1100 students, 52 students are school dropout in the last academic year which is $5.6 \%$.

The respondents said that they don't face any caste and gender issues from all the schools but except GTR school because the management and teacher are not approachable.

The constitution rightly says, Right to development, Right to protect, Right to live, Right to education is the right of every child in India who are under the age of 18 according to Constitution of India, these are the four basic rights which every child in India, under the rule of constitution need to have. Even though it is a Government residential school these rights are not even met. For nurturing a child basic facility are very rightful need for the growth and development of the children. Such as good education system, equipped classroom (which is must) when it comes to a vulnerable community for the development, it is highly required but Government is failing to shed light upon it.

\section{Recommendation}

The following were the recommendations made by the researcher based on the findings of the study:

\section{Ministry of Tribal Affairs}

Consciousness raising to minimize and eradicate the school dropouts and basic infrastructure of GTR School has to be enhanced, frequency of transportation has to be improved. To concentrate more on developmental education and the post of School Counselor has to be appointed. There is an urgent need to review the functioning and impact of these institutions and facilitate changes. 
DOI: https://doi.org/10.47405/aswj.v5i2.135

\section{Tribal Welfare Department}

As these schools comes under department of tribal welfare, the recommendation were made Indigenous practices should be taken care to prevent it from extinction. Co curricular and extra curricular activities has to be given importance as the quality of education includes all. Boys health camp has to be regularized. The lack of monitoring of institutions poses a problem so that they allow for inbuilt monitoring and review.

\section{Tribal Residential school}

The Peer pressure has to be taken into consideration as it prevails. Reinforcing Moral support for family attachment as they stay away from home. The quality of food need to be improved. Cocurricular and extra-curricular activities has to be given importance and the innovations include new teaching-learning materials, pedagogies and some texts and also consciousness raising to minimize and eradicate the school dropouts.

\section{Social Work Implication}

Social work is an integral part of human development as a social worker we have to work as a facilitator, educator to help the tribal people understand the importance of education. Social Workers are trained mental health professionals who can assist with mental health concerns, behavioral concerns, positive behavioral support, academic, and classroom support, consultation with teachers, parents, and administrators as well as provide individual and group counselling/therapy in school in need of attending to the physical, emotional, educational needs and spiritual wellbeing of Middle adolescence. As a social worker it is must to implement advocacy and lobby to implement better educational system for indigenous people to promote fundamental rights of children such as right to development, right to education and right to participation. Tribe social work helps a professional to understand the issues of tribes and attempts to engage in this issue a help develop a subaltern perspective. It helps to relate social theories to the existing social realities and develop an understanding of it. Social worker should conduct a research, consciousness raising for the welfare and development of tribal people through policy making.

\section{Conclusion}

The Tribal residential schools which plays important role in the increase in education access among the Tribes in Jawadhu hills, Tiruvannamalai. The are main reason behind the educational empowerment of the tribe are provision of free study materials, uniforms, residence, and food. Even though the implementation of developmental schemes such as (Umbrella Scheme) for education of ST Students for deprived section is not full-fledged, it has created some impact. If the state has taken enough measure to ensure to attain maximum efficiency in implementing the developmental schemes, then only the real empowerment is possible.

This study will help one to understand the role of educational institutions in equipping the children, impact of education and influence of environmental issues among the students pursuing secondary and tertiary school education which may result in the development of knowledge, attitudes and skills of a student.

To conclude, Education is the basic right of children especially for the vulnerable community and education is must there should be inclusive education for exclusively tribal. As said by Nelson Mandela "Education is the most powerful weapon which you can use to change the world". It can contribute to nation building and reconciliation so, the interest of the administrators with regard to tribal educational development is in the way such as, the amount of money spent and the number of schemes implemented, but the basic problem is whether is they are successful or not. 


\section{References}

Balagopalan, S., \& Subrahmanian, R. (2003). Dalit and Adivasi children in schools: some preliminary research themes and findings. IDS Bulletin, 34(1), 43-54.

Bairathi, S. (1991). "Tribal culture, economy and health" Rawat Publication, Jaipur,India.

Bapat, N.V. (1994). A few thoughts on Tribal Education, Vanyajathi Journal, 4-49.

Brickell H.M., (1958), 'An Analysis of Certain Non Instructional Staff Expenditures, (Doctoral Thesis) Columbia University: Teachers College, Columbia University.

DAS, R.C., (1974), 'Impact of School Conditions on Primary Education'. Assam: State Institute of Education.

Dr. Baiju K.Nath, et al (2015) E kalavya Model ResidentialSchool for Tribal Students in Wayanad, https://www.academia.edu.

Dhal, Debanjani. (2008). Educational Development of SC's and ST's and Tamil Nadu Government Budget: A Critique, in B.S. Padhi and B. Padhy (Eds.), Trends and Issues in Tribal Studies, Delhi: Abhijeet Publication.

Census (2011). Directorate of census operation, Government of India. Retrieved from $\mathrm{http}: / /$ cencusindia.gov.in/2011 census/data_files.pdf

Dr Gautam N (2013). Education of Scheduled Tribe in India: Schemes and Programmes. Journal of Education and Practice, 4(4).

Gadgil, D.R., \& Dandekar, V.M. (1991). Report of Two Investigations- Primary Education in Satara District, Gokhale Institute of Politics and Economics, Pune.

Geddam M S (2015) A Study on Eklavya Model Residential Schools (EMRS) In Tribal Education, Voice of Research, 3(4), 48.

Goldhaber, D. D. 1996. "Public and Private High Schools: Is School Choice and Answer to the Productivity Problem?" Economics of Education Review, 15(3).

HaseenaV.A (2014) Scope of education and dropout among tribal students in Kerala -A study of Scheduled tribes in Attappady. International Journal of Scientific and Research Publications, $4(1)$.

India. (2007). Ministry of HRD, Department of Higher Education: Status of Education in India; National Report, prepared by National University of Education Planning and Administration, $\mathrm{p}$. 18.

Jha, J and Jhingran.D, (2002). "Review of Elementary Education for Poorest and Other disadvantaged Groups: The Real Challenge of Universalisation." Centre for Policy Research. New Delhi.

Khan, (2000). Tribal Life in India, RBSA Publishers SMS Highway, Jaipur, 1-10.

Kumar, K. (1983). Educational Experience of Scheduled Castes and Tribes. Economic and Political Weekly, 18 (36/37), 1566-1572.

Mark S., (2002), Do School Facilities Affect Academic Outcomes? National clearing house for educational facilities. http://www.edfacilities.org/pubs

Mohan, S.,(1989) Tribal Development In India, Background Reading Material, Seminar on Training programme on Tribal Development and its Administration, conducted by Anna Institute of Management, Madras, p.45.

Muthukumar U. \& Tamilenthi S., (2013). A study of academic problems of tribal students of higher secondary schools in kolli hills in Namakkal district. Journal of Multidisciplinary Scientific Research, 1(3), 31-38

Prajina. P V (2009). A Study on the Academic Achievement Motivation among the Tribal children with special reference to Kannur district Kerala, IOSR Journal Of Humanities And Social Science (IOSR-JHSS), 15-17

Roy Burman, B.K, (1996). "problems of tribal language in education-A supplement to the special problems of tribes" Vanyajathi Journal.

Singh B. A, et al (2012) Tribal Education and Residential Schools: A Case from Sholaga of Erode District. International Journal of Social Science Tomorrow, 1(8).

Srivastava, L.R.N ,(1996) ."The problem of integration of the tribal people", 'The Indian journal of Social work". Kurukshethtra, .67-76.

Survey (2011). Anthropological Survey, Government of India. Retrieved from http://ansi.gov.in/2011formidable/data_files.pdf 
Asian Social Work Journal (ASWJ), Volume 5, Issue 2, (page 25 - 31), 2020

DOI: https://doi.org/10.47405/aswj.v5i2.135

Sujatha K, (1994). Educational Development among Tribes: A Study of Sub Plan Areas in Andhra Pradesh. New Delhi: South Asian Publication. 